\title{
Europe's migration agreements with migrant-sending countries in the global South: a critical review
}

\author{
Aderanti Adepoju, Femke van Noorloos \& Annelies Zoomers
}

Author manuscript published as article in International Migration 2010, 48 (3), pp. 42-75, doi 10.1111/j.1468-2435.2009.00529.x

(C) 2017. This manuscript version is made available under the CC-BY-NC-ND 4.0 license http://creativecommons.org/licenses/by-nc-nd/4.0/

Abstract

The past two decades have seen the steady emergence of various bilateral and multilateral migration agreements between Europe and migrant-sending countries in the global South.

This article provides a critical assessment of the way the EU - and individual countries such as Spain, France and Italy - have played active roles in reshaping old and developing new strategies for keeping migration under control while opening up new opportunities for "regular" migration. It also discusses the extent to which migration agreements help migrant-sending countries in Africa, Asia and Latin America to optimize the link between migration and development. Based on an analysis of the contents of the migration agreements and their implementation, it has become obvious that there is still a long way to go to achieve "fair multilateralism" and create "win-win" situations between the EU and the poorer migrant-sending countries in Africa, Asia and Latin America.

Aderanti Adepoju is director of the Human Resources Development Center and professor of economics at the University of Lagos (Nigeria). Email:

AAderantiadepoju@aol.com

Femke van Noorloos (Anthrpology) is PhD student (University Utrecht, Radboud Univeristy) involved in a study on residential migration in Central America. Emainl: femkevannoorloos@gmail.com

Annelies Zoomers is professor of Human Geography (International Development Studies) at Utrecht University and Professor of International Migration at the Radboud University in Nijmegen, the Netherlands. Email: a.zoomers@geo.uu.nl 


\section{Introduction}

The European Union, with 27 member states, about 500 million inhabitants and a share of global GDP of 31 per cent, has the potential to assume global responsibility and take up the role as a protagonist of fair and effective multilateralism in the area of international migration (Messner, 2007). The establishment of the free movement of labour under the Single European Act and the creation of a borderless Europe under the Schengen Agreement have brought to the fore the issue of external immigration into the European Union. Today it has been recognised that there is a need to establish a common EU immigration policy to replace fragmented and inconsistent national regimes.

Only recently, since the 1990s, the EU and individual European countries have become actively involved in migration, playing an increasingly important role in establishing bilateral and multilateral agreements with a number of migrant-sending countries in Africa, Asia and Latin America.

These agreements often address a wide range of different aims such as preventing and combating irregular labour migration, including admission procedures and arrangements for repatriation, social security, family reunification, integration and return. Other agreements aim at expanding avenues for regular labour migration while taking into consideration labour market needs and demographic trends in the various countries as well as the ethical recruitment of health professionals from poor countries. They may also have more general goals such as fostering an improved migration management mechanism through cooperation, capacity-building and dialogue between the countries involved (the last in the context of the 2001 Berne Initiative). The question arises then: to what extent does this provide a basis for a truly global and integrated approach to migration? And are these agreements moving into the direction of a fair multilateralism which could contribute to poverty-alleviation on a global scale?

This article provides a critical assessment of how the EU and individual countries such as Spain, France and Italy play active roles in shaping the link between migration and development, developing new strategies for keeping migration under control while opening up new opportunities for "regular" migration. They are setting the stage for the possibilities and restrictions for migrant-sending countries especially in Africa to benefit from migration. More specifically, we review the objectives of these agreements, analyse how they were implemented, and draw a conclusion about the long-term development implications for the countries involved. Is there a common goal and do these agreements offer opportunities for optimising the development impact of migration while minimising the negative implications? ${ }^{1}$

The article is based on fieldwork and internet research carried out in 2007. We contacted relevant ministries (especially relating to justice and immigration) of certain selected African countries with large emigrant populations, to solicit pertinent information (which was very difficult to obtain) on the bilateral agreements they have entered into with EU countries; held interviews with representatives of European 
embassies in Abuja, Nigeria as well as various African embassies in the Netherlands and Belgium; and collected additional information by approaching key informants working in advisory and research capacities on international migration. Finally, we conducted an extensive search of policy documents, including parliamentary documents, regulations and laws, as well as newspaper articles, research articles and internet materials.

In the sections that follow, we will show that bilateral and multilateral migration policies between European countries, on the one hand, and migrant-sending countries on the other, have passed through different stages. We will first analyse the "oldest" agreements which are mainly aimed at controlling irregular migration and readmission agreements, giving detailed information about the situation in the Maghreb and Nigeria. We then discuss the more recent agreements on labour migration, paying close attention to circular migration and measures to stimulate the reversal of brain drain and referring to Spain's agreements with Latin America and the EU's pilot project with Mali. The focus then shifts to the current attempts to incorporate development aid as a part of bilateral and multilateral migration agreements through the example of "co-development" between Mali and France.

Finally, we address the issue of what lessons can be drawn on how migration agreements can help to make migration more development-relevant, showing the need to make the process more transparent and helping migrant-sending countries strengthen their negotiating power, followed by our final reflections.

\section{1. "Controlling migration": agreements aimed at solving the problems of irregular migration, readmission, and repatriation}

Europe has signed agreements with many countries aimed at controlling irregular migration and ensuring cooperation on the readmission of irregular migrants. Specific readmission agreements have been concluded with Albania, Russia, Sri Lanka, Macao, and Hong Kong, while negotiations are ongoing with other states. Besides these, individual EU member states, often going to great lengths to press source and transit countries to cooperate with them on the repatriation of irregular migrants) have also been active in signing their own readmission agreements. ${ }^{2}$

In recent years, due to factors such as economic growth and the postSeptember 11 reinforcement of US security and immigration services, the EU has increasingly become a magnet for immigrants. As a response to rising levels of immigration from Africa, the EU decided to tighten controls at its external borders, especially on the Mediterranean coast. This was followed by the implementation of the EU common external border policy, executed by FRONTEX (the European Agency for the Management of Operational Cooperation at the External Borders of the Member States of the European Union).

Today, the EU and its member states (in particular France, Italy and Spain) provide African and Mediterranean countries with substantial financial and personnel 
support in controlling borders, fighting human trafficking and strengthening their police and intelligence apparatus. For example, in response to increasing levels of irregular migration from Mauritania, Senegal and Cape Verde, the EU decided to intensify patrols in West African waters and increase police cooperation in exchange for generous development aid packages to these countries.

These measures reportedly have resulted in decreasing levels of migration from sub-Saharan Africa. During the first three months of 2007, for example, there was a 60 per cent drop in numbers of migrants arriving at the Spanish Canary Islands: in comparison to 2006, the number had gone down from 3,914 to 1,525 (PICUM, 2007b). At the same time, however, FRONTEX operations (and outsourcing the responsibility of stopping migrants to the Maghreb) have resulted in a southward shift of migration networks and an intensification of migration industries (helping migrants in border-crossing, etc.). The tougher anti-migration efforts in Senegal has resulted in Senegalese trafficking networks changing their main departure point to further south into Guinea-Bissau - prompting Bissau authorities to ask Spain for economic assistance to stop the new flow.

In addition to pushing migration pressure further to the south (instead of solving the problem of irregular migration), the "externalisation" of the EU border controls has also resulted in human rights problems. Examples of human rights violations taking place in the Maghreb countries are numerous (Directorate-General, 2006) (see also sections 1.1 and 1.2). Unfortunately, European police and immigration services have not always taken human rights seriously. A Gambian television broadcaster once accused Spain of collaborating with the infamous Gambian National Intelligence Agency (NIA) in its fight against irregular migration. The NIA has been severely criticised due to accusations of systematic torture, disappearances and probable political liquidations (Afrol News, 22 November 2006).

The externalisation of migration control to sub-Saharan Africa and the Maghreb may also lead to violations of the "non-refoulement" principle. ${ }^{3}$ The EU external border agency FRONTEX has carried out various operations called "Hera", ${ }^{4}$ in collaboration with Spain, Senegal, Mauritania, and Cape Verde. These show a serious lack of adequate asylum screenings before returning would-be migrants to their origin countries (ECRAN Weekly Update, 3 November 2006), but evidence shows that a fairly large number of transit migrants caught in the Mediterranean did actually come from countries where their lives were in danger (Betts \& Milner, 2006). As the consequence of the current policy of "refugee retention in the regions of origin" and "keeping refugees removed as far as possible" from Europe's border (Betts \& Milner, 2006), transit migrants and refugees have often become more vulnerable. This was witnessed in 2003 when Malta repatriated a large number of Eritrean refugees, which led to their imprisonment and torture in their countries of origin (Directorate-General, 2006).

An important problem in guaranteeing human rights - and providing for better protection - is the lack of transparency and increased "informality" surrounding migration agreements. Currently, many EU member states have shown a preference for informal and flexible agreements, especially with African states. 
Arrangements for repatriation and migration control (as well as incentives such as development aid and preferential entry quota) are increasingly established outside formal agreements (Cassarino, 2007). This means that not only these arrangements are less transparent and controllable by parliaments, but also that human rights guarantees are often lacking. Even when the agreements are formal and published, politically sensitive issues such as financial clauses and collaborating institutions are often arranged outside the formal agreement. In that way, governments are able to collaborate with all kinds of institutions, such as local intelligence services and private security companies, without parliamentary control.

\section{$1.1 \quad$ The Maghreb}

The introduction of tougher rules regarding regular migrants' entry to and residence in Europe, has, since the mid-1990s, inadvertently pushed irregular West African migrants to use complex routes to reach the Maghreb as a transit region, in order to enter Europe clandestinely (Adepoju, 2006). In the process, Morocco has become a major transit-migration country for irregular migrants from West Africa and beyond. They enter the country from Algeria at the border east of Oujda after crossing the Sahara through Niger and attempt to enter the EU countries via the Strait of Gibraltar, which separates Morocco from Spanish Andalusia, or via the Strait of Sicily, which separates Tunisia from Italy, and increasingly, via the 240 kilometres that separate the Canary Islands from the Spanish mainland. About 2,000 Africans are believed to drown in the Mediterranean each year while attempting irregular crossings to Europe.

Following the deaths of irregular migrants attempting to penetrate the fence around Ceuta, an enclave of Spain on the African mainland, on 29 September 2005, the EU Commission's technical mission to Morocco visited Ceuta and Melilla almost immediately after and concluded that the mounting migration pressure from Africa on Morocco and the EU would intensify in the coming years.

The EU found it necessary to provide substantial assistance to ensure the longterm sustainability of the control efforts and proposed to increase cooperation with and provide assistance to Morocco. In addition, the EU aimed at launching a dialogue and initiating cooperation with Algeria and developing a comprehensive migration policy for the main countries of origin and transit in West Africa and indeed in subSaharan Africa as a whole (EC, 2005). From July 2006, the EU's new approach has been to push for re-admission agreements under which African countries will take back irregular migrants in exchange for economic assistance. An agreement has been negotiated with Morocco for the readmission of migrants: in addition to taking back its own nationals, the EU demands that Morocco also return those from other countries who transited to Europe through its territory (comparable offers have also been made to other African countries).

In addition to this EU strategy, individual EU member states have been trying to secure the cooperation of Maghreb countries by concluding bilateral agreements. The following bilateral agreements are indicative of the growing interest in curtailing irregular migration and ensuring the return and readmission of irregular migrants: 
-Bilateral agreement between Tunisia and Italy, signed in 1998, for facilitating the readmission of irregular nationals and third-country citizens in transit;

-Bilateral agreement between Morocco and Spain in September 1999 for facilitating the readmission of Moroccan nationals as well as transit migrants; subsequent bilateral agreements were signed between Morocco and Spain $(2004,2006)$ on the cooperation of intelligence services in the fight against human trafficking, joint marine patrols, etc.;

-Bilateral agreement between Libya and Italy in 2003 involving financial support for combating smuggling and providing sea-rescue operations; in 2004, another agreement was signed between the two countries providing financial support for the training and equipment of Libyan control personnel and the construction of three identification centres for migrants. Both of these were followed by agreements signed in 2005 for Libya to hold African refugees and irregular migrants in detention camps to prevent them from crossing to Europe.

Irregular migrants who lack legal status are vulnerable to social and economic marginalisation and rarely have access to or enjoy decent employment. Xenophobic situations in countries such as Morocco and Libya have often aggravated their situation. The Moroccan media intensified negative sentiments by comparing these people to "black locusts" (Al-Shamal, 12 September 2005), prompting the authorities to subsequently round them up to be deported to the Algerian border. The authorities in Libya and Morocco have bullied and expelled this group of transit migrants, often sending them to desert border posts where they face hunger, torture and even death. In a forest near Morocco's border with Ceuta, encampments have been set up by destitute Africans, who have reportedly been attacked and arrested by the Moroccan police.

In June, 2005, when Libya signed an agreement with Italy to hold sub-Saharan African refugees and irregular immigrants in detention camps to prevent them from crossing to Europe, the head of France's Information and Support Group for Immigrants called the policy "the most symbolic example of European cynicism ... externalising its asylum and immigration policy by getting third countries to take responsibility for the flow of migrants before they arrive at its borders" (Amnesty International, 2005). Non-Libyans have been picked up by the police, thrown into camps and expelled en masse, without recourse to any human rights protection. The European Parliament noted that Libya "practises arbitrary arrest and detention" and spoke of "the detention [and] massive repatriation of foreigners in conditions which do not guarantee their dignity or survival" (EC, 2004b).

In all, bilateral agreements and cooperation in coastal areas and along land borders, aimed at curtailing and controlling irregular migration and the readmission of repatriated immigrants, remain the dominant strategy between European countries 
bordering the Mediterranean and the Maghreb countries of migrant transit and origin. Critics argue that the implementation of bilateral agreements ignores migrants' rights and accuse Morocco of bowing to pressure from the EU to play the role of "Europe's policeman" in North Africa (Belguendouz, 2006).

\subsection{Nigeria and Italy}

Nigeria is a major source, transit and destination country for women and children trafficked to Europe for the purposes of sexual exploitation, forced labour and child labour, especially to Italy (where there may be as many as 10,000 Nigerian prostitutes), Spain, Belgium and the Netherlands as well as to other African countries (Adepoju, 2004). Nigeria has endorsed most international agreements against human trafficking, played a key role in the Economic Community of Western African States' (ECOWAS) anti-human trafficking initiatives, and entered into bilateral agreements and memoranda of agreement on immigration matters with countries within and outside Africa on human trafficking, forced labour and migration in general (Adepoju, 2005). These agreements focus mainly on procedures for the repatriation of Nigerian nationals.

Key among the Nigerian bilateral migration agreements are:

-Agreement on Immigration Matters between the governments of Nigeria and Ireland, signed 29 August 2001. This agreement is aimed at facilitating the readmission of Nigerian irregular migrants. It has not yet been ratified, but both countries are operating in the spirit of the agreement (Quinn, 2007).

-Agreement on Migration Matters between Nigeria and Spain, signed 12 November 2001 and ratified on 30 November 2002. The agreement deals with the readmission of irregular migrants, the fight against human trafficking, the protection of victims, the exchange of information on trafficking networks, cooperation on reintegration (in the field of HIV/AIDS), the establishment of skills acquisition centres in Nigeria for returned migrants, etc. (Adepoju, 2004). As a result of the agreement, over 1,000 irregular migrants were repatriated in both 2002 and 2003 and approximately 900 in 2004 .

-Cooperation Agreement between the governments of Nigeria and the United Kingdom, signed in November 2004, to prevent trafficking in persons and to suppress and punish traffickers. It calls for greater sensitivity on the part of the UK's immigration and law enforcement officers and includes strategies to ensure the protection of trafficked persons as well as technical and institutional capacity-building to prevent trafficking, protect victims and prosecute offenders. Other aspects are related to programmes to provide counselling for the physical, psychological and social rehabilitation of trafficked victims (personal communication, British High Commission, Abuja). 
-Agreement between the governments of Nigeria and Italy. In the framework of bilateral cooperation in combating irregular immigration, Italy donated equipment and goods to the Nigerian government with a value over US\$ 2.5 million in 2002. A second round of donations took place in 2004 (of goods worth $€ 786000$ ) and a third in 2005 and 2006 (with a value of about $€$ 4 million) for distribution among governmental agencies involved in immigration control and the monitoring and investigation of human trafficking. ${ }^{5}$

Italy is, as was stated before, a major country of destination for trafficking in women and children from Nigeria and ranks among the top nine destination countries for sex trafficking in the world (Associated Press, 12 May 2003). In a determined effort to curb the trafficking of human beings, Italy provides (as a part of the readmission agreement with Nigeria) technical and material assistance, including training courses, to irregular migrants in the case of their readmission. As a part of the reintegration process at home, there is provision for cooperation in the control of HIV and other sexually transmitted diseases.

In addition, Italy financed a multi-bilateral programme to prevent and combat the trafficking of children and women from Nigeria to Italy. The project was implemented by the United Nations Interregional Crime and Justice Research Institute (UNICJRI) and the United Nations Office on Drugs and Crime. During the first phase, bilateral cooperation was strengthened by creating in both countries a task force to deal with human trafficking from Nigeria to Italy. In the fight against trafficking and organized crime, Italy also established a National Monitoring Centre in Abuja, managed by the National Agency for the Prevention of Trafficking in Persons (NAPTIP), with the aim of exchanging information and creating a databank of information about victims involved in and/or rescued from trafficking. The memorandum also covered rehabilitation and reintegration activities by providing micro-credit to help victims acquire skills and set up small businesses of their own.

There has been a recent wave of repatriation of Nigerian girls, mostly victims of human trafficking, from Italy. Under Italian migration law, victims of human trafficking and prostitution, who denounce their abusers and testify against them, are entitled to the same protection similarly given to those who speak out against the Mafia and are provided with shelter and assistance. However, a great discrepancy exists between the text and its implementation. Deported women have claimed that they were denied the opportunity of taking advantage of legal provisions. Many Nigerian women deported from Italy recount the indignities they suffered, often detained in holding centres prior to being expelled and not being allowed to return to their places of residence to collect the belongings they had acquired during their stay. The Nigerian agreement with Italy is also of no help, as it does not make any specific mention of human trafficking, nor clarify the conditions under which victims of human trafficking are to be repatriated (Nwogu, 2005).

Up to now, Nigeria, in their negotiations about migration agreements, has not yet succeeded in getting guarantees from Italy and other countries for the protection of its nationals abroad and/or ensuring that readmissions comply fully with 
international standards for the protection of the rights of migrants and trafficked persons. The country's consular offices in destination countries should provide information to migrants about their rights and obligations. In addition, the governments of destination countries should guarantee the humane treatment of victims of human trafficking during repatriation and assist more actively in providing capacity-building and institutional support to the Nigerian government agencies responsible for tackling the problem of human trafficking (Nwogu, 2006).

\section{Labour migration agreements: between cherry-picking and reversing brain drain}

Although most bilateral migration agreements between the EU and the migrants' countries of origin still focus predominantly on migration control and readmission, emphasis has been slowly shifting from "repressive measures" to cooperation by the boosting of economies, opening more channels for regular migration to the EU and encouraging circular migration.

During the 1970s, bilateral labour migration agreements, especially those directed towards low-skilled migrants, were frequently used by European states to satisfy their labour market needs - with guest workers coming from Spain, Italy, Turkey, and Morocco. Nevertheless, following the 1980s' economic decline, increasing unemployment rates and the expansion of the EU, this guest workers programme came to an end and nowadays, most EU countries have reduced entry possibilities for low-skilled labour migrants from outside the EU.

Today, to the extent that countries use bilateral migration agreements to attract labourers from other parts of the world, this is mainly reserved for migrants from a few countries (i.e., Spain, Italy and Portugal). Spain and Italy have concluded agreements including labour migration with Eastern European, Maghreb, Asian and Latin American countries, but cooperation with sub-Saharan Africa has steadily been increasing, as recent Spanish agreements with Senegal, Guinea and the Gambia show. Recently the European Commission as well as some EU member states have shown a renewed interest in labour migration quotas and will probably experiment with these in the future.

The renewed interest by the EU in introducing multilateral workers' schemes probably has as much to do with preventing irregular migration as with their actual labour market needs. As for the first objective, European experiences with labour migration agreements leave no doubt that, although they may provide a certain number of migrants with an opportunity to migrate in a regular situation --and with reasonable working conditions, as these agreements take into account the migrants' labour rights and often oblige employers to pay for airplane tickets, accommodation costs, etc.-- it has not yet been sufficient to provide a solution for the problem of irregular migration (EC, 2004a). Despite various Spanish labour migration projects with Eastern European and Latin American sending countries, regular labour migration still forms a relatively small part of the total flow of labour migrants to that 
country (Serra, 2005). It has proven difficult to ban irregular migration due to the fact that irregular workers are such a vital part of the Spanish labour market and many employers have an interest in maintaining low salary-levels. Yet, the quotas set by the Spanish National Employment Agency are small in comparison to the number of irregular migrants :

Both employers and labour unions agree that the 2002 labour quota did not solve the problem of irregular migration. While the government set a quota of 32,079 workers (10,884 permanent workers and 21,195 temporary workers), it was widely viewed as falling short of meeting labour needs. In particular, some labour unions estimated that another 10,000 workers were necessary in the agricultural sector. In 2003, the quota was fixed at 24,337 foreign workers $(10,575$ permanent workers and 13,762 temporary workers). By reducing the quota for temporary workers to almost 10,000 less than the 2002 number, the government has signalled that it continues to seek to limit immigration (Ortega Pérez, 2003).

In Italy, Nigeria is one of the countries that is enjoying preferential treatment for its labour migrants, in addition to Argentina, Albania, Morocco, Tunisia, Egypt, Moldova, Sri Lanka, and Bangladesh (Chaloff \& Piperno, 2004). Nigeria is, thus far, the only sub-Saharan African country to benefit from a quota. In 2002, a reserved entry-quota for admittance into Italy was granted for the first time - to 500 Nigerian workers - in recognition of the Nigerian government's collaboration efforts on combating irregular immigration. This quota was then continued and increased, after a low 200 in 2003, to 2,000 in 2004 and 2005, and reaching 2,500 in 2006.

Besides the "symbolic character", the instability and conditionality of labour quotas are factors that further reduce the effectiveness of these agreements. Italy's readmission agreements are exemplary in this respect. Italy has introduced a "preferential quota" system which guarantees preferential access to labour visas for migrants from countries that cooperate on readmission and migration control. In practice, however, these preferential quotas are set at a very low number and make up only 25 per cent of the total number of labour visas issued by Italy (OECD, 2004). Moreover, no reference to the preferential quotas is made in the bilateral agreements themselves, enabling Italy to adapt them according to the situation. In fact, Morocco was "punished" in 2001 for a presumed lack of cooperation by having its preferential quota lowered which hit an extreme low in 2003. (Chaloff \& Piperno, 2004).

The conditionality surrounding bilateral labour agreements can lead to instability and a lack of transparency regarding regular labour migration possibilities for migrants from southern countries to the EU. These problems are exacerbated by the dependence of potential migrants on European labour market needsa phenomenon which can actually increase irregular migration.

\subsection{Circular migration}


Recently, much attention has also been given to "circular migration," which is increasingly perceived as a perfect combination of interests benefitting all parties--the sending countries, receiving countries and migrants ("circular" migration means that migrants come to the receiving country only for a certain length of time, intending from the outset to return home at the end of the work period). It allows migrants to gain experience and skills and apply these after returning to their countries of origin, thereby contributing to development and transforming brain drain into brain gain while simultaneously satisfying particular labour market needs such as seasonal labour.

Doubts exist, nevertheless, as to the viability of circular migration and its real implications. The doors to permanent stay are inexorably closing, but as long as significant job creation and development in countries of origin is not taking place, migrants will prefer to stay permanently in the host countries and even bring their family members over. They may use circular migration as an opportunity to enter and stay permanently in irregular situations. In order for return to become a reality, for brain drain to be reversed and for returned migrants to contribute to development (that is, to maximise the development impact of circular migration), some level of economic development and job creation in the countries of origin is needed; emigration forms a complement to internal economic growth, not an alternative. Another factor that could influence the migrants' likelihood of returning is the duration of the visa; if the duration is considered non-optimal by the migrant, this could negatively affect their decision to return home (Awad, 2006).

Taking circular migration as a fact and a future strategy, an important question that arises is how to prevent migrants from overstaying their visas and ensure their return to their countries of origin. Specific measures are needed to make return materialise. In most of Europe's labour migration agreements, it remains unclear, however, how the problem of return is to be solved. The following examples illustrate the type of measures that are currently implemented:

-In January 2007, Spain issued 700 labour migration visas to Senegalese fishermen. These visas will be renewable for migrants who have found employment after their first year (Christian Science Monitor, 29 March 2007). However, this in no way guarantees that the migration will be circular.

-In a project between the Spanish town of Cartaya and Morocco, co-financed by the EU, seasonal labour migrants were recruited in 2006 from Morocco for the strawberry harvest. When it turned out that more than half of these migrants did not return to Morocco after the specified period of time, it was decided in 2007 to recruit only mothers with children in order to guarantee their return.

In the Canadian seasonal workers programme with countries such as Guatemala and Mexico, seasonal migrants are assured that their visas will be renewed for the following year, but only if they comply with the obligation to return to their home country for the interim period (Christian Science 
Monitor, 29 March 2007; OSCE, 2006).

-In Spain's agreements with Ecuador and Colombia, seasonal workers must make themselves known at the Spanish Embassy in their countries of origin after the expiry of their contract in order to leave the doors open for visa renewal. However, it remains unknown how many of these workers actually return. As a part of the labour migration policy between Spain and Colombia, a pilot project is currently being implemented, with the help of the EU and IOM, under which extra services, such as reintegration programmes with micro-credit facilities, centres for migrant counselling, etc., are offered to migrants on return (e.g. reintegration programmes with micro-credit facilities, centres for migrant counselling, etc.) (EC, 2007). Economic incentives, such as the payment of social security benefits, have also been suggested. Savings plans under which migrant workers are obliged to put a part of their salaries into a savings account, which they can access only when they return, are already operational in countries such as Taiwan and selectively in the United States and the UK (Agunias, 2007). While these measures could serve to create more political will and open up possibilities for labour migration, they go against labour rights conventions (Awad, 2006).

Recently, analysts and policy makers have suggested that more open and more flexible temporary-worker programmes could increase their development-friendliness for the countries of origin (Agunias, 2007). Return incentives such as multiple-entry visas could be a part of these programmes. Another measure that could prove helpful is the possibility of longer migration contracts. Seasonal or even one-year contracts currently the most common for low-skilled migrants - do not give migrants enough time in the host country to accumulate sufficient savings for them to contribute to development in a significant way, by setting up a business, for example (Agunias, 2007). Additionally, it is now often argued that more flexible temporary worker schemes are needed that do not tie migrants to a particular employer, but instead enable them to change jobs. These types of schemes are already operational in the UK's Highly Skilled Migrant Programme and would make migrants more independent and less subject to abuse and exploitation (Agunias, 2007).

\subsection{Reversing brain drain?}

A particular form of labour migration is the migration of highly qualified workers or students. This is a type of migration that the EU is increasingly trying to encourage, as there is a growing need for qualified personnel and many EU countries make efforts to attract the most talented migrants. The possibilities for the entry of highly qualified migrants are often incorporated into the migration policies of European countries, who are acting unilaterally. A number of EU countries, the UK, France, Germany and the Czech Republic, for example, have opened up possibilities for selecting (especially highly-skilled) labour migrants (IOM, 2006:6). 
Since attracting highly qualified migrants is mainly in the EU's own interest, visas for these migrants are usually not made dependent on collaboration in migration control, readmission or similar bilateral arrangements. Receiving countries often act unilaterally and countries of origin can at best try to improve conditions in reaction to these policies. For example, in the negotiations on the France-Senegal bilateral agreement, France fixed the criteria for "selective migration" and Senegal hardly had a say in the selection of highly qualified migrants and students. It was only in the subsequent bilateral agreement that the two countries decided to "select together those who will migrate" (Wabgou, 2007). How this will work out in practice has yet to be seen.

It is relatively recently that more attention has been paid in migration agreements to reduce the negative consequences of "brain drain," taking into account the "ethical considerations." Some destination countries take measures to stimulate highly qualified migrants to return to their country of origin after some years, allowing them to travel back and forth and attempting to reverse a brain drain. France has established a special circulation visa to this end in its agreement with Senegal. The three-year "talents and competences" visa in its general migration law can be renewed only once, while additional measures have been included to facilitate the migrants' contributions to the development of their countries of origin.

In addition, another way to reverse the brain drain is through so-called "codes of conduct," which are especially applied in the health sector). South Africa has experienced an exodus of health professionals to various countries around the world, who have in part been attracted by higher wages and a perception of greater personal security and also in response to active recruitment by destination countries. This has led to a worrying loss of doctors and other medical staff, especially in the rural areas, while health issues, most notably the HIV/AIDS pandemic, remain critical. In response, the UK, one of the primary destinations of South African doctors, implemented a "code of practice" prohibiting the National Health Service from actively recruiting doctors and nurses from countries like South Africa (Hamilton \& Yau, 2004). What this agreement did not incorporate, however, were the recruitment policies of private medical centres in the UK and hence, South Africa continued to lose qualified medical staff, albeit at a lower rate.

Another bilateral agreement between the UK and the Philippines demonstrates a range of best practices in the field of ethical recruitment. The agreement sets out in detail the requirements placed on the Philippine Overseas Employment Administration (POEA) to ensure transparency and eliminate abuse. The costs are shifted from the individual migrant to the client as the NHS pays for much of the initial costs (IOM, 2006). The Philippines' longstanding policy of encouraging the emigration of its citizens, regulating recruitment and protecting the rights of emigrants may have been a crucial factor in the success of this agreement.

Currently, many schemes for temporary return are being implemented by international organisations, often in collaboration with various governments, to enable migrants to contribute to development in their countries of origin. The IOM's Migration for Development in Africa (MIDA) and the UNDP's Transfer of 
Knowledge through Expatriate Nationals (TOKTEN) projects are exemplary for their focus on temporary return as opposed to permanent return (IOM, 2006). These programmes encourage highly-skilled migrants to return to their countries of origin for short periods to contribute to development by giving lectures or by doing volunteer work as doctors, for example. Still, these schemes tend to be small in scale. It is therefore important that the residential laws of receiving countries be made flexible to give skilled professionals the opportunity of relocating to their countries of origin and contributing to development without losing their residence rights in the host countries (Adepoju, 2007; also Adepoju, van Naerssen \& Zoomers, 2008).

Besides the actions taken by destination countries, countries of origin also play important roles in reversing brain drain. The source countries' national policies can also contribute to the return of their migrants. Taiwan is notable for the important role return migrants are playing in developing the economy. Some lessons that can be learnt from the Taiwanese experience are that governments from southern migrantsending countries should actively engage in building networks with their diasporas to build a "brain reserve" which can be called upon later and that their education policies should be adapted to employment needs (O’Neil, 2003). China is another example of a country aiming to attract return migrants with measures that range from offering them privileges related to housing, jobs and schools to the establishment of Chinese Scholars Pioneering Parks, where returnees can enjoy special treatment in starting their own businesses (Leung, 2007).

\subsection{Spain and Latin America}

During the 1980s and 1990s, Spain shifted from being an emigration country to an immigration country. Immigrants from Latin America formed a large part of those arriving in Spain during these decades. Today, Latin American immigrants, numbering just over 1 million, make up 35.2 per cent of the total foreign population in Spain (Padilla, 2007).

Spain has been struggling to forge an immigration policy to adapt itself to its new status. In 2001, Spain signed bilateral agreements on the "regulation of labour migration flows" with Ecuador, Colombia and the Dominican Republic (the agreement with the Dominican Republic formally entered into force only in 2007). These agreements, which give due consideration to migrants' rights, create administrative frameworks for regular migrants to obtain access to the Spanish labour market and fight against irregular migration. An amendment of Law 4/2000 on the "rights and freedoms of foreigners in Spain and their social integration" (2001) paved the way for a reform of work and residency permits and visas as well as a renewed emphasis on controlling irregular migration,following the EU policy. This in turn led to the signing of cooperation accords with the main sending countries to manage

migration flows from the points of origin (Ortega Pérez, 2003). In addition to Ecuador, Colombia and the Dominican Republic, Spain has signed bilateral agreements with Morocco, Nigeria, Poland, and Romania.

While Latin American citizens have long been exempted from needing tourist visas to enter Spain, the Spanish government, from 2003 onwards, decided to start 
requesting visas from Ecuadorians, Colombians, Dominicans and Bolivians in order to better control the inflow of migrants from these countries.

Spain has devised various labour quota systems to respond to shortages in the labour market, set up in 1993-1995, 1997-1999 and in 2002 (Ortega Pérez, 2003). The quota system was reformed in 2002, because before that time it had had the effect of regularising many undocumented migrants who were already in Spain rather than attracting new migrants. The government now establishes annual quotas for foreign workers and before work permits can be granted, the National Employment Institute must issue a report on the nation's employment situation (Ortega Pérez, 2003).

Foreign labour can be considered only if there are no appropriate national workers available. Also, the Spanish government now issues work permits only to nationals from countries with which bilateral agreements have been established and only citizens living in these countries of origin can apply. For example, in Ecuador, between September 2002 and May 2005, 1,891 migrants were selected to work in 125 Spanish companies, mainly in agriculture (30 per cent), hotel and restaurant services (23 per cent), cleaning (15 per cent), and retail (13 per cent) (Ministerio de Relaciones Exteriores Ecuador, 2005). Since 2005, more than 16,000 Colombians have participated in the programme (Müssig, 2006). No numbers are available regarding Dominican workers.

\subsection{Mali: the EU pilot project for labour migration}

During the past decades, but especially in recent years, migration flows from Mali have intensified. In the first months of 2007, over 10 per cent $(2,800)$ of the 26,000 irregular migrants arriving in Spain were Malians; the total number of Malians living in Europe are now estimated at 200,000, the majority of whom are concentrated in France.

On 22 January 2007, the EU Immigration Commissioner, Franco Frattini, unveiled a pilot project for a new "guest worker" scheme for Africa, which aims to boost local economies, enhance the earning potential of migrants, and consequently stop - or at least significantly reduce - irregular migration. This flexible scheme is designed to coordinate job offers in the EU with job seekers in Mali.

In pursuance of the new strategy aimed to fill jobs in areas of labour shortage (i.e., boosting the EU's aging workforce) as well as to stem the tide of irregular immigration and stimulate development, the EU Development Commissioner announced in early February 2007 that the EU planned to set up job centres for African migrants, first in Mali, then in Senegal and Mauritania. The aim of this scheme,--modelled on a project in Spain's southern province Andalusia, which was already receiving 1,000 agricultural workers from Morocco for six months each year,-is to help migrants find jobs in the EU in sectors such as agriculture, construction and sanitation services. With this idea, the EU aims to elicit job quota offers from member states for Mali workers and eventually plans to establish a network of job centres across Africa.

In addition, the EU's European Development Fund (EDF) also financed the Migration Information and Management Centre project in 2007, which was set up in 
Bamako. The aim is to implement the joint Mali-ECOWAS-EC-France-Spain Declaration of February 2007 as a follow-up to the 2006 Tripoli EU-African Ministerial Conference on migration and development. The general objective of the Centre is the definition and implementation by Mali of a migratory policy adapted to both regional and European policies and dynamics. In addition to informing Malians about job and training opportunities at home and abroad as well as about the dangers of migration, the Centre also aims to put in place a mechanism for welcoming, orienting and accompanying new migrants, productively using the human, financial and technical capital of the diaspora. The EU Development Commissioner Louis Michel remarked early in 2007 that the Centre "goes in the direction of the "third (alternative) way' which we are proposing to reach realistic and humane solutions to migration problems."

\section{Co-development agreements: the incorporation of development aid in migration agreements}

Until now, although the EU has been increasing border patrols against irregular immigration both on land and sea, the current strategy has been to offer more avenues for regular migration. In addition, there is a trend that migration policy and development aid are becoming increasingly interconnected.

In Europe nowadays, it is no exception to offer development aid to poor countries in exchange for cooperation on migration control and readmission. The linking of migration control and development started in 2003 with the inclusion of a migration paragraph, including an obligation of readmission, in the Cotonou agreement between the EU and the Africa, the Caribbean and the Pacific (ACP) countries.

At the end of September 2006, the EU and Mali signed a migration control agreement in exchange for development aid. Under this agreement, the EU promised to grant Mali $€ 426$ million over the period from 2008 to 2013, with the funding going mainly into poverty reduction projects which should help to better control migratory flows. The EU's expectation is that economic growth, productive investment, support of the private development sector, and regional integration could substantially boost job creation in Mali and halt the flow of irregular migrants as well as strengthen efforts to fight the networks organising irregular migrations.

The EU and Senegal carried out two short-term cooperation projects in 2006: a contribution to surveillance operations, repatriation and rehabilitation (about $€$ 1.8 million) and providing local support for activities of non-state actors engaged in migration ( $€ 1$ million). The plan in the medium-term is to invest in public projects ( $€$ 19.8 million to $€ 27.4$ million) to create about four thousand jobs in a year ${ }^{6}$ (EU business 2006). Besides Mali and Senegal, Morocco and Mauritania have also signed potentially lucrative agreements with the EU and Guinea-Bissau will probably be the next to do so. 
Also, individual countries such as Spain have started offering development aid in exchange for the cooperation of mainly African countries of origin in the fight against irregular migration. In 2006, Spain offered Gambia and Guinea each $€$ 5 million in direct development aid in exchange for signing global migration agreements involving readmission, migration control, and labour migration. Senegal has been promised $€ 10$ million for a similar agreement (El Mundo, 9 October 2006).

While the shift from restrictive, often penalising, measures to a more facilitative approach of offering development aid and tackling the root causes of migration may seem positive, caution is needed in assessing its value as the increased link between development and migration policy may have harmful long-term effects. For example, making cooperation on migration a condition for gaining development funds could lead to an undesirable situation where the main countries of departure and transit of irregular migrants to Europe secure extra funds while other, possibly poorer, countries without direct migrants towards Europe are excluded from development aid. [6] France's co-development policy seems to have contributed to an allocation of development funds with a bias in favour of the main emigration countries over the poorest countries and the total budget spent by the former on development has been relatively low (Magoni, 2004).

In the EU, a proposal was made by the UK and Spain for punitive measure -mainly, the cutting of donor money -- in 2003 against countries that failed to actively collaborate in the fight against irregular migration. However, other member states objected and a much watered-down version of the initial proposal was accepted instead (Flynn, 2004: 8). In addition, Betts and Milner's analysis of regional refugee protection, financed by European donor money in Africa should also serve as a warning for the use of development aid for migration control (Betts \& Milner, 2006). They show how general refugee funds - such as that of the UN High Commissioner for Refugees - are receiving less, because European countries are increasingly financing the refugee protection programmes of individual African countries. This not only hampers the effectiveness of refugee protection, but it also leads to competition between African countries for donor money. This in turn divides Africa and increases Europe's negotiating powers. Countries of emigration and transit to Europe are usually in a relatively good position to claim additional development funding in return for fulfilling Europe's need for migration control, thus widening the gap with other countries of the South.

On the other hand, the new link between migration and development aid can also have positive effects. In Spain, migration pressure has put the whole African continent on the map during the past few years, causing it to triple its development budget for Africa in two years, reaching $€ 600$ million in 2006 (Moratinos, 2006a). Spain has not only increased its budget for migrant-sending (transit) countries, but it is also supporting various regional and global funds: it donated $€ 20$ million to a development fund, in collaboration with the World Bank, for West Africa (El Mundo, 22 November 2006), $€ 190$ million to a World Bank vaccination fund for the poorest countries, $€ 28$ million to an African Development Fund for debt relief (El Mundo, 10 July 2006), € 60 million to a global fund for combating HIV/AIDS, malaria and 
tuberculosis, and $€ 200$ million to a global debt relief fund that will benefit education, including in many African countries (Moratinos, 2006b).

It is worrying that under the cover of "co-development," an increasing part of Europe's official development aid is spent on migration control. For example, the Netherlands spends official development funds on capacity- building of the Ghanaian government directly related to migration control (Dutch Ministry of Foreign Affairs, 2006). The 2006 French-Senegalese bilateral agreement also provides an example of development money being spent on goals such as the modernisation of the Senegalese police apparatus (aimed at controlling irregular migration) and information campaigns against irregular migration. The same goes for Spain's agreements with the Gambia and Guinea, in which the development paragraph includes measures such as: capacity-building of migration-related institutions, development of a national migration policy, and information campaigns on migration and recruitment schemes. Additionally, various countries pay with development funds for humanitarian aid programmes to repatriated migrants. The humanitarian consequences of the EU's migration policy are thus dealt with using official development aid. It is therefore not surprising that these expenditures are politically-sensitive.

\subsection{Mali and France: co-development}

France has a long tradition of linking migration to development policy, known as "co-development." This means that official development aid is mainly allocated to the countries of origin of the main migration flows --often Francophone countries-and is also being instrumentally used to reduce irregular migration pressure (Magoni, 2004). This French model is strongly connected to specific migration systems and transnational networks of African migrants in France. Co-development policy is thus based on these social networks and existing development initiatives and aims to use them instrumentally to counter irregular migration (Aumüller, 2004). The policy is carried out mainly at local and regional government levels in collaboration with migrant organisations, although the new French migration law of 2006 aims to formalise it on a federal level.

The "Cooperative Efforts to Manage Emigration" project focuses on how countries of origin, transit, and destination can work together to coordinate migration movements and reduce emigration pressures. In that context, Mali, Comoros and Senegal have been targeted for co-development to link migration policies and development policies. As part of this co-development, Mali and France have established a "Consultation on Migration," signed in December 2000, which involves an annual bilateral discussion at the ministerial level, dealing with issues such as the integration of Malians who want to remain in France, the co-management of migration flows to allow migrants to circulate between their home countries and abroad and cooperative development in core emigration localities in Mali. The "Consultation" targets core emigration regions and helps them to build infrastructure, stimulate job creation, and support education, health care and infrastructure development as well as income generation (Adepoju, 2004; 2006). Malians abroad are 
mobilised for their country's economic development; their skills are registered and the information is co-managed by a Franco-Malian committee. A contract with a local Malian bank guarantees loans to small businesses that require additional funding for expansion. The agreement aims at stimulating migrants to return voluntarily and become self-supporting.

The funds previously used for forced repatriation from France to Mali are now used to encourage voluntary return in more humane circumstances while also providing sources of livelihood for the returnees, who were mostly unskilled migrants. Encouraging voluntary "assisted returns," rather than relying on mandatory deportation, are expected to better meet the interests of both sending and receiving countries (Adepoju, 2004). In 2001, about 500 immigrants agreed to return voluntarily to Mali in exchange for a compensation of $\$ 3,600$ per person to start businesses such as agriculture, hairdressing, importing used motor parts and sewing traditional clothes. More than two years after the start of the project, 80 per cent of these returnees are still in business (Martin et al., 2002). Although many returnees lack the local guarantees required for bank loans, this model of co-development helps to reintegrate migrants, who eventually become self-sustaining.

\section{Towards "fair" multilateralism?}

As we have seen, European interests such as migration control and readmission still dominate in the multilateral and bilateral migration agreements that are signed with migrant-sending countries in the South, while southern interests such as labour migration opportunities and development aid are often peripheral or even nonexistent. At the same time, however, there are a number of positive developments which could potentially result in "fair multilateralism" and creating win-win situations between poorer Southern partners and richer EU-countries, optimizing the development impact of migration.

To the extent that migration agreements do not yet reflect the interest of southern partners, power differences play an important part in this imbalance of represented interests. For example, in the negotiations on the migration component of the Cotonou agreement, the EU applied "pure power politics" (Woud, 2004:81) to defend its interests. Although the ACP countries fought fiercely against the inclusion of a component that would oblige them to take back their own nationals found in irregular situations in an EU country, they were not able to prevent it (Woud, 2004).

Another example of unequal power relations can be seen in the negotiations between France and Senegal regarding the 2006 agreement. Following its new migration law, France took the initiative of developing an agreement with Senegal the latter being able to change only some of the components of the original proposal. As a result, Senegalese interests were weakly represented in the agreement, while France was able to secure cooperation on readmission, migration control and the migration of highly skilled migrants. Despite the enhanced negotiating power that countries such as Senegal have achieved over the last years due to their key role in dominating the main migration routes to Europe, they still do not seem prepared nor able to defend their interests in an optimal way (Cassarino, 2007; Wabgou, 2007). 
Differences do exist, however, as to the positions that different European countries take in the negotiations of bilateral agreements and the situation often is rather complex and contradictory. As we explained above, France often acts unilaterally in the case of readmission agreements, but has exhibited a spirit of cooperation in the case of "co-development projects." Countries such as Mali, but also Cameroon and Gabon, are nowadays becoming more self-confident and "critical," having refused to sign further readmission agreements with France (PICUM, 2007a). It also remains to be seen whether Senegal will comply with its obligation to readmit its nationals. It is not so clear to what extent southern partners will succeed in designing their own agenda and forcing EU-countries to collaborate.

Spain seems to be relatively successful in concluding migration agreements that are cooperative and based on partnership. The lack of colonial bonds with the main African emigration countries could be seen as a blessing in that this enables negotiations from more egalitarian positions. Spanish diplomacy in Africa has intensified since 2006 and Spain is already cooperating with many countries on migration issues. Senegal's positive appraisal of Spanish cooperative efforts on migration is a model for Spain's success in creating new relations.

It is of vital importance that African, Asian and Latin American countries develop their own perspectives on how to deal with the receiving countries in the case of migration, so that their interests are better represented in bilateral and multilateral agreements. Cooperation on a regional and multilateral level could provide these countries with greater negotiating power with respect to the EU. In addition, it would be helpful if these countries would develop their "own" migration policies, which are often lacking.

Many regional southern economic communities or other kinds of regional integration programmes are developing policies for the free movement of their citizens within these communities. However, in view of the conflicting interests and difficult decision-making processes which accompany the formation of these communities, it is not surprising that a true free movement has not yet materialised in most of them. For example, ECOWAS members such as the Gambia, Guinea-Bissau, Mali, Senegal, Cote d'Ivoire, and Mauritania seem to be regularly repatriating migrants to fellow-ECOWAS countries or even imprisoning them. In addition, the Southern African Development Community (SADC) still has a long way to go in terms of the free circulation of persons. On the other hand, European initiatives and agreements which aim at controlling African borders are impeding free circulation and good bilateral relations between those countries, as has been made especially clear in the relations between Mahgreb and sub-Saharan African countries (De Haas, 2006).

Other types of regional consultation processes, joint declarations and conferences, set up with the help of IOM, help countries develop integral migration policies and bring them in tune with each other. The Regional Conference on Migration (CRM, also called the Puebla Process) in North and Central America and the South American Migration Conference (CSM or Lima Process) are examples of these initiatives. They are relatively new and still focus strongly on information 
exchange and research, but are also making a start with common policies on migrants' rights and establishing return programmes. Other examples include the Dakar Process in West Africa and the Bali Process in Southeast Asia and the Pacific (Ratha \& Shaw, 2007). Strengthening these processes of regional integration might help migrantsending countries to speak with one voice and restoring the power balance in favour of the African, Asian and Latin American partners.

\section{Final Reflections}

In conclusion, bilateral and multilateral agreements signed by the EU or its individual member states with migrant-sending countries have passed through various stages, changing from one-sided measures to more inclusive approaches in which some of the responsibility has also shifted to home countries mainly in Africa. Whereas migration agreements have simultaneously become more collaborative and inclusive or "global", we also conclude that most migration agreements continue, primarily, to reflect the agenda of the EU and that they serve mainly to control and preferably limit migration. Benefits of these agreements to the southern partners, such as increased levels of development aid seldom reflect a fundamental interest to eradicate poverty, but rather serve to legitimise the implementation of policy measures that constrain migration. Hence migration-related agreements that would truly serve the interests of both the southern and northern partners are called for. In such agreements, countries of the South, especially African countries, may need to form a common agenda of interests to offset the agenda of the EU.

During the first phase, the concern in Europe was with rounding up irregular migrants and victims of trafficking and deporting them from Europe back to their countries of origin. In most cases, this was done without consultation with the countries of origin and was often affected under inhumane conditions and in breach of the rights of the expellees. Emphasis shifted during the second phase in the direction of having more "dialogue and consultation" with the sending countries, with the objective of guaranteeing the readmission at home of the irregular persons to be expelled. A part of this strategy was the tightening of border controls in what became the "fortressing of Europe" and zero tolerance of irregular migration to be followed by the outsourcing of responsibility for the policing of borders and shifting the responsibility of halting irregular migrants from the EU to Morocco, Libya and Algeria.

The third phase involved rewarding sending countries which "cooperate" with donations of technical and operational equipment to make the home place more desirable and thus contain irregular emigration from the source. The "carrot" part of this carrot-and-stick strategy rewards cooperative sending countries by granting work quotas for their nationals in receiving countries. This "carrot" also legitimises the presence of the "stick": measures with which border control is intensified in order to stop any informal passage.

In the last, most recent, phase there is an increasing recognition that strict controls do not necessarily produce the desired results. Instead, these restrictions 
incite migrants to choose informal migration routes, inadvertently spurring trafficking. Hence, EU countries have proposed to invest in job creation, economic growth and poverty alleviation schemes in Africa in order to stem the tide of irregular emigration and/or stimulate development. This strategy also includes circulatory migration schemes, whereby Africans are allowed to work legally, albeit temporarily, in specific sectors of EU countries with severe labour shortages and programmes for reversing brain drain. EU policymakers concerned with migration are increasingly coming to terms with the interconnectedness of the economies of the EU and the South through migration and providing a basis for "fair" multilateralism.

One of the major problems with Europe's migration agreements with migrantsending countries is, however, that EU countries are still the dominant architects: the southern countries are often persuaded to fall in line and implement the agreements, while not providing much critical input in the negotiations leading to these agreements. Southern countries need to ensure that their specific interests and concerns are adequately reflected in any bilateral and multilateral migration negotiations, so that migration issues are no longer used by European countries as a condition for receiving development aid.

Development aid, but also labour migration possibilities, which the EU offers to countries of the global South, should preferably remain disconnected from efforts to collaborate on migration control and repatriation. Otherwise patron-client relationships will arise between the EU and specific countries of the global South based on the threat of migrant numbers rather than on common goals to achieve sustainable, profitable economic relationships. Indeed, relationships may be achieved at the expense of those developing countries which are poorest and most vulnerable yet do not pose a migration "threat" to the EU.

Examples of issues that are not yet sufficiently covered in migration agreements between southern partners and the EU include the rights of irregular migrants to basic services and the need to review unfair trade regimes. These topics should be given centre stage in future migration agreements. To the extent that negotiations take place at the level of the EU, southern countries should no longer act as individual countries but should aim at formulating policies at the regional level so that they can counterbalance the power of the EU. This calls for a strong commitment of the governments of neighbouring countries to forsake possibly conflicting national interests for the benefit of the entire region.

Based on our analysis of the state of affairs in migration agreements, we have to conclude that in the current situation, "benevolent actors" are still acting in their best interests and there is still a long way to go in achieving "fair multilateralism" and creating "win-win" situations between the EU and migrant-sending countries in Africa, Asia and Latin America. It is to be hoped therefore that the EU could assume global responsibility and take up the role as a protagonist of fair and effective multilateralism, creating a "development-enabling" migration environment. 


\section{References}

Adepoju, A.

2004

"Regional migration processes, multilateral and bilateral migration agreements in sub-Saharan Africa", IOM: Berne Initiative Policy Research Papers. Berne: International Organisation for Migration.

2005 "Review of research data on trafficking in sub-Saharan Africa", International Migration, 43 (1 \& 2).

2006 "The challenge of labour migration flows between West Africa and theMaghreb", ILO Migration Research Papers. Geneva: International Labour Organisation.

2007 "Highly skilled migration: balancing interests and responsibilities and tackling brain drain", Global Forum on Migration and Development, Brussels, Civil Society Day.

Adepoju, A, T. van Naerssen \& A. Zoomers

2008 International migration and national development in sub-Saharan Africa.

Viewpoints and policy initiatives in the countries of origin. Afrika-

Studiecentrum Series Vol.10. Leiden/ Boston: Brill publishers.

Agunias, D.

2007

"Linking temporary worker schemes with development", Washington:

Migration Policy Institute,

http://migrationinformation.org/Feature/display.cfm?id=576.

Amnesty International

2005

"Spain/Morocco: the authorities must be held accountable for the violation of migrants' rights", Press Release, 26 October 2005.

Aumüller, J.

2004.

"Migration Control through Codéveloppement? In Migration and Political Intervention. Theories and Debates", Berlin: Europäisches Migrationszentrum,

http://www.emz-berlin.de/projekte_e/pj41_pdf/Aumueller_Code.pdf.

Awad, I.

2006

“Acuerdos y programas de migración temporal ”, commentary presented at the Encuentro Iberoamericano sobre Migración y Desarrollo (4 ${ }^{\text {th }}$ part), Madrid, 18-19 July 2006, http://www.crmsv.org/pagina_novedades.htm.

Belguendouz, A.

2006 Enjeux Migratoires Maghreb-Europe-Afrique Subsaharienne: Un regard $d u$ Sud. Sale: Imprimerie Beni Snassen.

Betts, A. \& Milner, J.

2006 "The externalisation of EU asylum policy: the position of African states”, Working Paper No. 36. Oxford University: Centre on 
Migration, Policy and Society,

http://www.compas.ox.ac.uk/publications/Working\%20papers/WP063

6-Betts-Millner.pdf.

Cassarino, J.

2007

“The 'new approach' to the readmission of illegal persons: operability versus transparency", This Century Review, January2007,

http://www.thiscenturyreview.com/The_New_Approach_to_the_Read mission_of.thenewapproach.0.html.

Chaloff, J. \& Piperno, F.

2004. "International migration and relations with third countries: Italy", in J.

Niessen \& Y. Schibel (Eds.) International Migration and Relations

with Third Countries. Brussels: Migration Policy Group,

http://www.migpolgroup.com/multiattachments/2571/DocumentName/

Italyforeignrelationsfullreport.pdf.

De Haas, $\mathrm{H}$.

2006

"Trans-Saharan migration to North Africa and the EU: historical roots and current trends",. Washington: Migration Policy Institute, http://migrationinformation.org/Feature/display.cfm?id=484.

Delicato, $\mathrm{V}$.

2004

National Legislation and Good Practices in the Fight Against Illegal

Migration - the Italian model. Rome: CARDS Programme.

Directorate-General for External Policies of the Union

2006 "Analysis of the external dimension of the EU's asylum and migration policies”,. Brussels: European Parliament, DGEPU, Directorate B,

Policy Department,

http://www.statewatch.org/news/2006/jul/eu-res-study-ext-imm.pdf.

Dutch Ministry of Foreign Affairs

2006 "Kamerbrief inzake derde rapportage migratie en ontwikkeling”,, http://www.minbuza.nl/nl/actueel/brievenparlement,2006/08/Kamerbri ef-inzake-derde-rapportage-migratie-en-ont.html.

Dutch Parliament

2006 Verslag algemeen overleg vaste commissie voor Justitie, 20 March 2006 (nr. 19637 - 1027 PubMed ), http://www.parlando.sdu.nl.

European Commission (EC)

2004a "Study on the links between legal and illegal migration”, Brussels:

EU,

http://eur-

lex.europa.eu/LexUriServ/site/en/com/2004/com2004_0412en01.pdf

2004b Report of Technical Mission to Libya on Illegal Immigration, 22

November-6 December 2004. Memo 7753/05 Brussels: EU.

2005 Visit to Ceuta and Melilla: Report of Technical Mission to Morocco on Illegal Immigration, 7-11 October 2005. Memo/05/380. Brussels: EU. 
European Migration Network (EMN)

2005

Irregular migration in Italy. Illegally resident Third Country Nationals in Italy. Rome: European Migration Network, http://www.emnitaly.it/down/pilotstudy2-english.pdf.

Flynn, D.

2004

"International migration and relations with third countries: the United Kingdom”. In J. Niessen \& Y. Schibel (Eds.) InternationalMigration and Relations with Third Countries. Brussels: Migration Policy Group, http://www.migpolgroup.com/multiattachments/2575/DocumentName/ UKforeignrelationsfullreport.pdf.

Hamilton, K. \& Yau, J.

2004 "The global tug-of-war for health care workers." Washington:

Migration Policy Institute, http://migrationinformation.com/Feature/print.cfm?ID=271 (accessed June 2007).

IOM

20032003 World Migration Report. IOM: Geneva.

2006 "Towards development-friendly migration policies and programmes: some concrete examples from European member states", Background paper prepared for IOM, Geneva, http://www.migrationdevelopment.org/fileadmin/data/conference/back Leung, M.W.H. ground_papers/INTConf_1_428200634447PM_01.pdf.

2007 "Migration, diaspora and development: the case of the People's Republic of China". In A. Adepoju, T. van Naerssen \& A. Zoomers (Eds.) International Migration and National Development in subSaharan Africa. Leiden: Brill Publishers.

Magoni, R.

"International migration and relations with third countries: France". In J. Niessen \& Y. Schibel (Eds.) International Migration and Relations with Third Countries: European and US approaches. Brussels: Migration Policy Group, http://www.migpolgroup.com/multiattachments/2567/DocumentName/ Franceforeignrelationsfullreport.pdf.

Martin, P., Martin, S. \& Best, P.

$2002 \quad$ "Best practices options: Mali”, International Migration, 40 (3): 87102.Messner, D.

2007 "The European Union: protagonist in a multilateral world order or peripheral power in the Asia-Pacific century? " Internationale Politik und Gesellschaft 1/ 2007: 11-27. 
Ministerio de Relaciones Exteriores Ecuador

2005

Boletín de Prensa No. 246, Quito.

Moratinos, $\mathrm{M}$.

2006a

"Discurso del Ministro Español de Asuntos Exteriores y de cooperación en la Conferencia Europa-África sobre migración y desarrollo", Tripoli (22 November2006). Madrid: Ministerio de Asuntos Exteriores, http://www.maec.es/es/MenuPpal/Actualidad/Declaraciones $+\mathrm{y}+$ discurs os/Discurso+Ministro20061122.htm.

Moratinos, $\mathrm{M}$.

2006b "España: una nueva política exterior hacia África”, Revista PoliticaExterior, 1 May2006. Madrid: Ministerio de Asuntos Exteriores, http://www.maec.es/es/MenuPpal/Actualidad/Declaraciones+y+discurso S/ESPAÑA+UNA+NUEVA+POLITICA+EXTERIOR+HACIA+AFRICA+Re vista+Politica+Exterior.htm.

Müssig, G.

2006

“Acuerdos y programas de migración temporal”, paper presented at the Encuentro Iberoamericano sobre Migración y Desarrollo ( $4^{\text {th }}$ part $)$, Madrid, 18-19 July 2006, http://www.crmsv.org/pagina_novedades.htm.

Naerssen, T. van, Ernst Spaan and A. Zoomers (eds)

2008

Global migration and development. New York: Routledge

Noll, G.

2006

"The Euro-African migration conference: Africa sells out to Europe", http://www.opendemocracy.net/peoplemigrationeurope/migration_confer ence_3738.jsp (accessed 27 April 2007).

Nwogu, V.

2005

"Trafficking of persons to Europe: the perspective of Nigeria as a sending country", paper presented at the ASI \& OIKOS Conference on Trafficking and Migration: a Human Rights Approach. NPC (Nigeria) - ILO/PATWA, http://www.nuoveschiavitu.it/ns/doc_leggi/relazione_nigeria.doc.

Nwogu, V.I.

2006

"Nigeria: human trafficking and migration", Forced Migration Review, Issue 25: 32-33, http://www.fmreview.org/text/FMR/25/20.doc (accessed May 2007).

O’Neil, K.

2003) "Brain drain and gain: the case of Taiwan", Washington: Migration Policy Institute, http://www.migrationinformation.org/Feature/display.cfm?ID=155.

Oropeza, J.A. 
"Gobernabilidad migratoria: integración, regularización y programas de migración laboral temporal", paper presented at the Encuentro Iberoamericano sobre Migración y Desarrollo ( $4^{\text {th }}$ part $)$, Madrid, $18-19$ July 2006, http://www.crmsv.org/pagina_novedades.htm.

OECD (Organisation for Economic Co-operation and Development)

2004. Migration for Employment: Bilateral agreements at a crossroads. OECD.

Ortega Pérez, N.

2003 Spain: orging an immigration policy. Washington: Migration Policy Institute, http://www.migrationinformation.org/Profiles/display.cfm?ID=97.

OSCE (Organisation for Security and Cooperation in Europe)

2006 Handbook 2006. Chapter IX, Interstate Cooperation. Vienna: OSCE, http://www.osce.org/publications/eea/2006/05/19187_631_en.pdf.

Padilla, B.

2007 "Latin American immigration to Southern Europe", Washington: Migration Policy Institute, http://www.migrationinformation.org/Feature/display.cfm?id=609.

PICUM (Platform for International Cooperation on Undocumented Migrants)2007a

Newsletter, February 2007, http://www.picum.org (accessed March 2008).

2007b Newsletter, May 2007, http://www.picum.org (accessed March 2008).

Quinn, E.

2007 "Research study 3: return migration from Ireland", Dublin: European Migration Network, http://www.esri.ie/UserFiles/publications/20070726111026/BKMNEX T087.pdf.

Ratha, D. \& Shaw, W.

2007 "Causes of South-South migration and its socioeconomic effects", Washington: Migration Policy Institute, http://www.migrationinformation.org/Feature/display.cfm?id=647.

Serra, A. 2005

"Current immigration debates in Europe: a publication of the European migration dialogue: Spain”, In J. Niessen, Y. Schibel \& C. Thompson (Eds.) Current Immigration Debates in Europe. Brussels: Migration Policy Group, http://migpolgroup.socialchange.net.au/multiattachments/3012/Docum entName/EMD_Spain_2005.pdf.

Wabgou, M.

2007 "Governance of migration in Senegal: the role of government in formulating migration policies", In A. Adepoju, T. van Naerssen \& A. 
Zoomers (Eds.) International Migration and National Development in Sub-Saharan Africa. Leiden: Brill Publishers.

Woud, F. terugkeerbeleid 2004.

\footnotetext{
${ }^{1}$ This study forms part of the research project "International Migration and National Development: Viewpoints and Policy Initiatives in the Countries of Origin", carried out by the Migration and Development Research Group of the Radboud University Nijmegen, and financed by the Dutch Ministry of Foreign Affairs and the Ministry of Social Affairs and Employment (see also Adepoju, van Naerssen \& Zoomers, 2008; also van Naerssen, Spaan \& Zoomers, 2008).

${ }^{2}$ In the recent bilateral agreements there is a tendency for a more 'integrated' approach: labour migration quotas and development aid are incorporated in readmission agreements in exchange for more cooperation on migration control.

${ }^{3}$ Non-refoulement is the idea that refugees who have reached the territory of a state cannot be forcibly returned to a country where they have a well-founded fear of persecution. It is arguably the most established tenet of the global refugee regime (Betts \& Milner, 2006).

${ }^{4}$ ] See http://www.frontex.europa.eu/newsroom/news_releases/art8.html.

${ }^{5}$ The agencies involved were the Nigeria Immigration Service, the Nigeria Police Force, the National Agency for the Prevention of Trafficking in Persons (NAPTIP), and the Ministry of Foreign Affairs. ${ }^{[6]}$ See also A. Zoomers and T. van Naerssen (2006) International migration and national development in sub-Saharan Africa. Viewpoints and policy initiatives in the countries of origin, Migration \& Development Research Series, Working Paper No. 1

(http://www.ru.nl/socgeo/html/files/migration/migration14.pdf)

${ }^{6} \mathrm{http}: / / \mathrm{www} . E u b u$ siness.com (accessed March 2008).
} 